\title{
Oral manifestation of plantar-palmar fibromatosis
}

\author{
Oluyori Kutulola Adegun, ${ }^{1}$ Abedalla Abdelghani, ${ }^{2}$ Farida Fortune ${ }^{1}$
}

${ }^{1}$ Centre for Clinical and Diagnsotic Oral Sciences, Institute of Dentistry, Barts and The London School of Medicine and Dentistry, Queen Mary University of London, London, UK

${ }^{2}$ Oral Medicine, Dental Institute, Royal London Hospital, Barts Health NHS Trust, London, UK

\section{Correspondence to} Professor Farida Fortune f.fortune@qmul.ac.uk

Accepted 25 July 2014

\section{(a) CrossMark}

To cite: Adegun $\mathrm{OK}$ Abdelghani A, Fortune $F$ BMJ Case Rep Published online: [please include Day Month Year] doi:10.1136/ bcr-2014-204962

\section{DESCRIPTION}

Palmar and plantar fibromatosis are benign, painless thickening in the aponeurosis of the hands and feet, respectively. ${ }^{1}$ Both forms of superficial fibromatoses can manifest as single or multiple nodular swellings resulting from localised proliferation of abnormal fibrous tissue in sites of predilection. ${ }^{2}$ Although, the rheumatological and characteristics imaging features of these rare diseases are well documented in literature, ${ }^{3}$ there are no reports of an oral manifestation.

We report a 54-year-old woman who presented at the oral medicine clinic with widespread, discrete and multiple polyp like nodules of variable size scattered on the dorsal surface, lateral borders and tip of the tongue (figure $1 \mathrm{~A}-\mathrm{C}$ ) Physical examination revealed Dupuytren's contractures on the palmar surfaces of both hands (figure 1D, G) and on the plantar surface of the right foot (figure 1E). In addition, a painless, firm and fixed nodule (knuckle pad) was observed on the plantar aspect of the left foot (figure $1 \mathrm{H}$ ). This was despite previous surgical intervention which resulted in the loss of a toe digit (figure $1 \mathrm{~F}$ ) and a postoperative scar (figure 1I). Although asymptomatic, the patient expressed concern about the risk of malignant transformation arising from the oral manifestation reported in this article. She was reassured that the risk was very low. Regular follow-up was initiated to monitor any further changes that may arise.

\section{Learning points}

Systemic diseases can manifest in the mouth.

- Dentists play an important role in the recognition and multidisciplinary medical management of rare systemic diseases.

\section{Competing interests None.}

Patient consent Obtained.

Provenance and peer review Not commissioned; externally peer reviewed.

\section{REFERENCES}

1 English C, Coughlan R, Carey J, et al. Plantar and palmar fibromatosis: characteristic imaging features and role of MRI in clinical management. Rheumatology (Oxford) 2012;51:1134-6.

2 Fetsch JF, Laskin WB, Miettinen M. Palmar-plantar fibromatosis in children and preadolescents: a clinicopathologic study of 56 cases with newly recognized demographics and extended follow-up information. Am J Surg Pathol 2005;29:1095-105.

3 Walker EA, Petscavage JM, Brian PL, et al. Imaging features of superficial and deep fibromatoses in the adult population. Sarcoma 2012;2012:215810
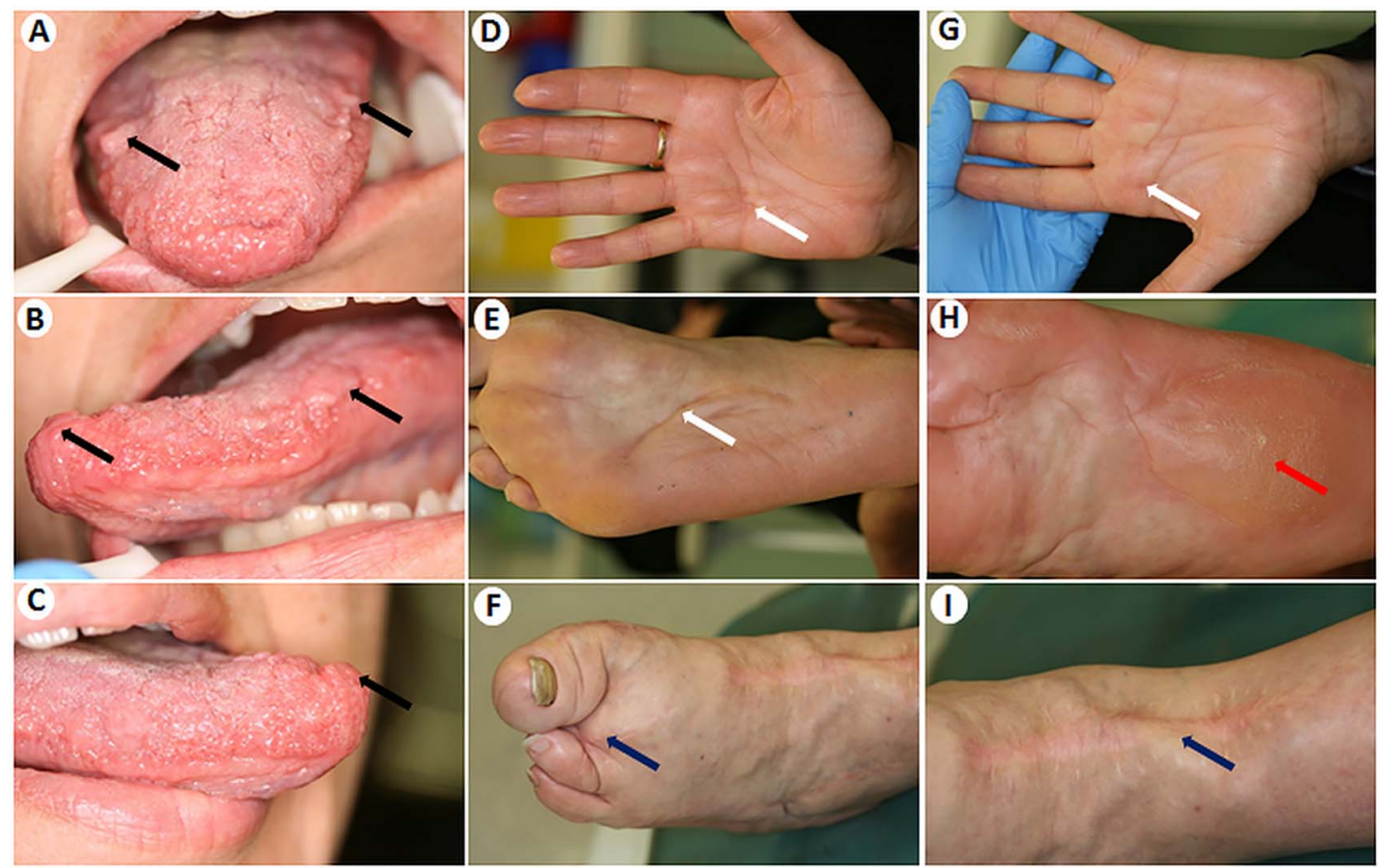

Figure 1 Discrete, multiple, asymptomatic tumour-like/nodular growths on the dorsal surface and lateral borders of the tongue (Black arrows in A-C), Dupuytren's contractures on the palmar surfaces of both hands and the plantar surface of the right foot (White arrows in $D, E$ and $G$ ), painless, firm and fixed nodule on the plantar aspect of the left foot (Red arrow in $\mathrm{H}$ ) and the resultant loss of a toe digit and post-operative scar following surgical intervention (Blue arrow in $\mathrm{F}$ and $\mathrm{I}$ ). 
Copyright 2014 BMJ Publishing Group. All rights reserved. For permission to reuse any of this content visit http://group.bmj.com/group/rights-licensing/permissions.

BMJ Case Report Fellows may re-use this article for personal use and teaching without any further permission.

Become a Fellow of BMJ Case Reports today and you can:

- Submit as many cases as you like

- Enjoy fast sympathetic peer review and rapid publication of accepted articles

- Access all the published articles

- Re-use any of the published material for personal use and teaching without further permission

For information on Institutional Fellowships contact consortiasales@bmjgroup.com

Visit casereports.bmj.com for more articles like this and to become a Fellow 